\title{
Syntheses and Biological Activities of Analogs of Abscisic Acid ${ }^{\dagger}$
}

\author{
Takayuki OrITANI and Kyohei Yamashita \\ Department of Agricultural Chemistry, Faculty of Agriculture, \\ Tohoku University, Sendai \\ Received October 11, 1973
}

\begin{abstract}
Selenium dioxide oxidation of methyl $\alpha$-ionylideneacetate (IIb) in ethanol afforded methyl $1^{\prime}$ - and $4^{\prime}$-hydroxy- $\alpha$-ionylideneacetate (IIIb and IV), methyl $3^{\prime}$-hydroxy- $\beta$-ionylideneacetate (V) and crude dihydroxy-ionylideneacetate (VI). The latter was oxidized with active manganese dioxide to give methyl abscisate (Ib). The growth and germination-inhibitory activity of compounds related to abscisic acid on Azuki bean seedlings and some species of seeds were examined.
\end{abstract}

In previous papers ${ }^{1,2}$ the authors reported that analogs of 2 -cis, $\alpha$ - and $\beta$-ionylideneacetic acids, having the same skeleton as abscisic acid (ABA), possess strong growth-inhibitory activities on rice seedlings, but their homologs with shorter side-chains ${ }^{3)}$ and longer sidechains $^{4}$ do not. Recently Popoff et al. ${ }^{51}$ suggested that a skeleton of citrylideneacetic acid $\left(\mathrm{C}_{12}\right.$-acid), rather than of ionylideneacetic acid is sufficient for growth inhibition by structures related to ABA on the basis of experiments with barerooted Black Valentine seedlings (Phaseolus vulgaris L.). Generally the activity of growth regulators may differ by species and variety of test plants, as the case of analogs of gibberellic acid $\left(\mathrm{GA}_{3}\right)$. In rice seedling tests, the activity of ABA analogs found by us was similar to that obtained by Tamura et $a l^{\text {b) }}$ despite the use of different varieties. In the case of Phaseolus vulgaris, the difference of activity due to varieties is still not clear. Furthermore, it was known that the activity of the ester form of $a$-ionylideneacetic acid, which was used as a standard sample by Popoff et al., was weaker than that of the free acid (IIa) on rice seedlings, so we re-examined the activity of compounds related to ABA on two varieties of Phaseolus vulgaris L. seedlings, pea and

$\dagger$ Studies on Abscisic Acid. Part IX. This report was presented at the 8 th International Conference on Plant Growth Substance, Tokyo, Japan, August 29 (1973). soybean seedlings. The data ${ }^{7)}$ on their inhibitory activities showed that compounds having an ionylideneacetic acid skeleton were generally more active than their lower homologs $\left(\mathrm{C}_{10 \sim 13}\right.$ compounds) and the activities of compounds related to $\mathrm{ABA}$ vary considerably with variety of Phaseolus vulgaris L. Here, the authors describe syntheses of some hydroxyionylideneacetic acids, and the biological activity of compounds related to ABA on Azuki bean seedlings (Phaseolus angularis L.) and some species of seeds. It was also demonstrated that analogs of ionylideneacetic acids are more effective than their lower homologs for germination inhibition of seeds.

\section{Syntheses}

Previously the oxidation of methyl 2-cis- $\alpha$ ionylideneacetate (IIb) with selenium dioxide in dioxane ${ }^{1 /}$ was attempted, giving a mixture of methyl keto- and hydroxy-ionylideneacetates. The separation of each hydroxy-ionylideneacetates from this mixture was difficult. Here, selenium dioxide oxidation of IIb in ethanol was successfully carried out to give a separable mixture of methyl hydroxy-ionylideneacetates as follows. IIb was oxidized with selenium dioxide in ethanol at room temperature for 6 days and the products was separated by silica-gel column chromatography, yielding methyl 2-cis-1'-hydroxy- $a$-ionylideneacetate (IIIb), ${ }^{6)}$ a small amount of methyl 2-cis-4'hydroxy- $\alpha$-ionylideneacetate (IV) ${ }^{2}$ and mainly 
allylic rearrangement products, methyl 3'hydroxy- $\beta$-ionylideneacetate $(\mathrm{V})$, the latter consisting of 2-cis and trans form (stereoisomers). At the refluxing temperature of ethanol, IIb gave a crude methyl dihydroxy-ionylideneacetate (VI) in addition to the above monohydroxy-esters. The dihydroxy-ester (VI) was further oxidized with active manganese dioxide in chloroform to give methyl abscisate (Ib).

\section{Biological activity}

Growth-inhibitory activity on Azuki bean seedlings

As shown in Table I, analogs of ionylideneacetic acids showed stronger growth inhibition of the second and third internodes (terminal meristem) than of the first internode. Probably this indicates inhibition of cell fission and cell elongation of the terminal meristem rather

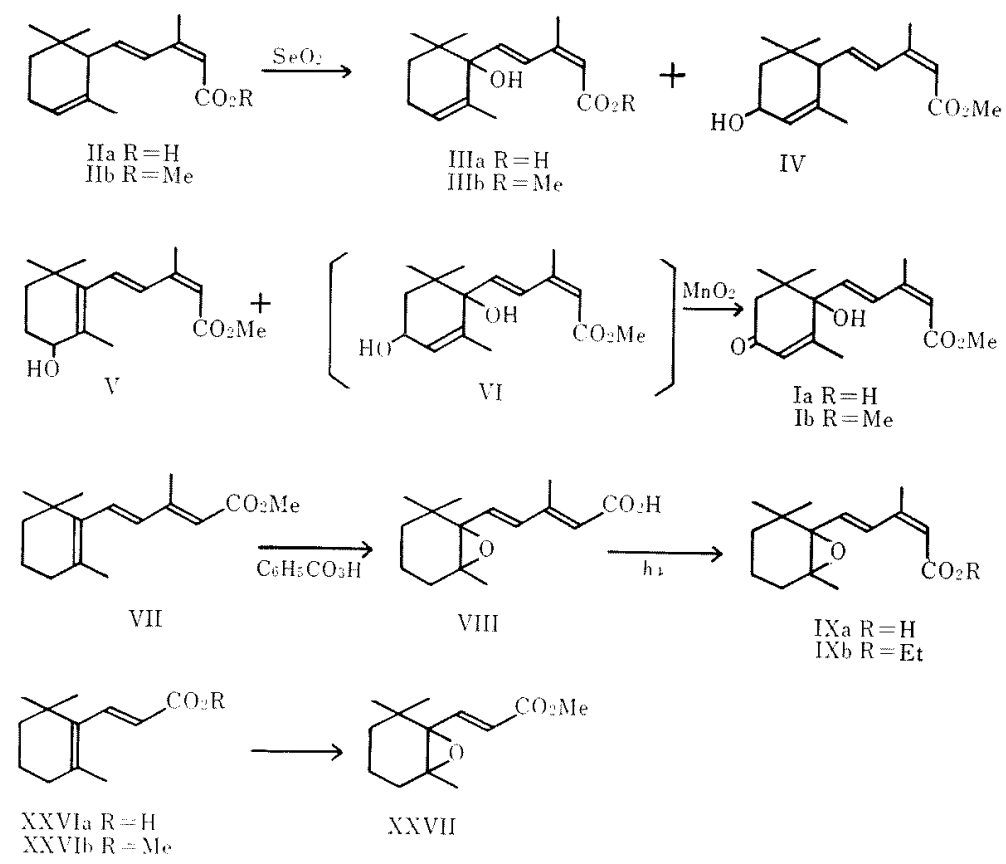

SCHEME 1.

Also, 2 -cis-epoxy- $\beta$-ionylideneacetic acid (IXa), which has strong growth inhibitory activity on rice seedlings, $\left.{ }^{\beta}\right)$ was prepared by photo-isomerization of 2-trans-epoxy- $\beta$-ionylideneacetic acid (VIII), which was easily prepared by epoxidation of methyl 2-trans- $\beta$ ionylideneacetate (VII) with perbenzoic acid followed by alkaline hydrolysis. Further, as one of the lower homologs $\left(\mathrm{C}_{12}\right.$-acid), methyl epoxy- $\beta$-cyclocitrylideneacetate (XXVII) was prepared by epoxidation of methyl $\beta$-cyclocitrylideneacetate (XXVIb) in chloroform. Other compounds tested for biological activity are listed in Fig. 1. than of the first internode, which almost completed cell fission. Analogs of ionylideneacetic acids showed stronger growth inhibitory activity than their lower homologs on Azuki bean seedlings, and ABA showed the strongest inhibitory activity among analogs of ionylideneacetic acids.

Interaction of some inhibitors with $G A_{3}$ on rice seedlings

The growth of rice seedlings (Oryzae sativa L. var. Honenwase) was promoted by $\mathrm{GA}_{3}$ $\left(10^{-4} \mathrm{M}\right)$ and this growth-promoting action of $\mathrm{GA}_{3}$ was suppressed by IIa as well as ABA at 


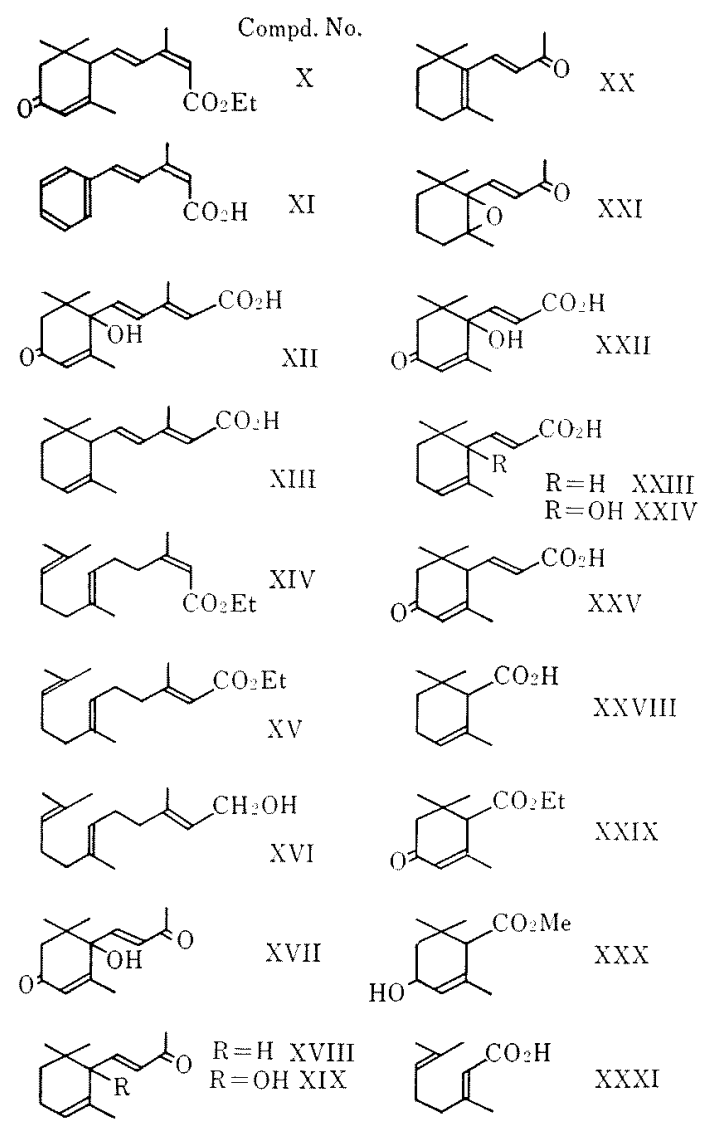

FIG. 1.

concentrations of $10^{-4} \sim 10^{-7} \mathrm{M}$, as shown in Fig. 2. On the other hand, XXVIa did not suppress this action, but slightly promoted it. Therefore, it was considered that the mechanism of weak inhibition of XXVIa may differ from those of analogs of ionylideneacetic acids.

\section{Germination-inhibitory activity}

Lettuce (Lactuca sativa L. var. Great Lakes). Germination of lettuce seeds was strongly inhibited in light rather than in the dark by analogs of ionylideneacetic acids (Table II). Interestingly, 2-trans isomers (XII, XIII) showed the strong inhibition in light. The homologs with shorter side chains $\left(\mathrm{C}_{10} \sim \mathrm{C}_{13}\right.$ compounds) showed weak or almost no activity. The increase of activity in light was considered probably due to activation of some enzyme converting the inhibitors into active forms in light. Farnesol (XVI), a precursor of $\mathrm{ABA}$, showed weak activity in light.

Leaf mustard (Brassica juncea Coss). Analogs of 2-cis- $\alpha$-ionylideneacetic acid and their 2-trans isomers (XII, XIII) showed inhibition of germination, but analogs of cyclocitrylideneacetic acid did not, as shown in Table II.

French marigold (Tagestes patula L.). ABA itself, among the analogs of ionylideneacetic acids, showed the strongest inhibition of germination. Some lower homologs (XXVIa, XXVII and XXIX) showed weak activity at $10^{-4} \mathrm{M}$, as shown in Table II.

Radish (Raphanus sativus L. var. Nerima) and Oat (Avena sativa L. var. Zenchin). The germination of both radish and oat seeds was weakly inhibited by analogs of 2-cis-ionylideneacetic acids, but scarecely inhibited by analogs of cyclocitrylideneacetic acid and

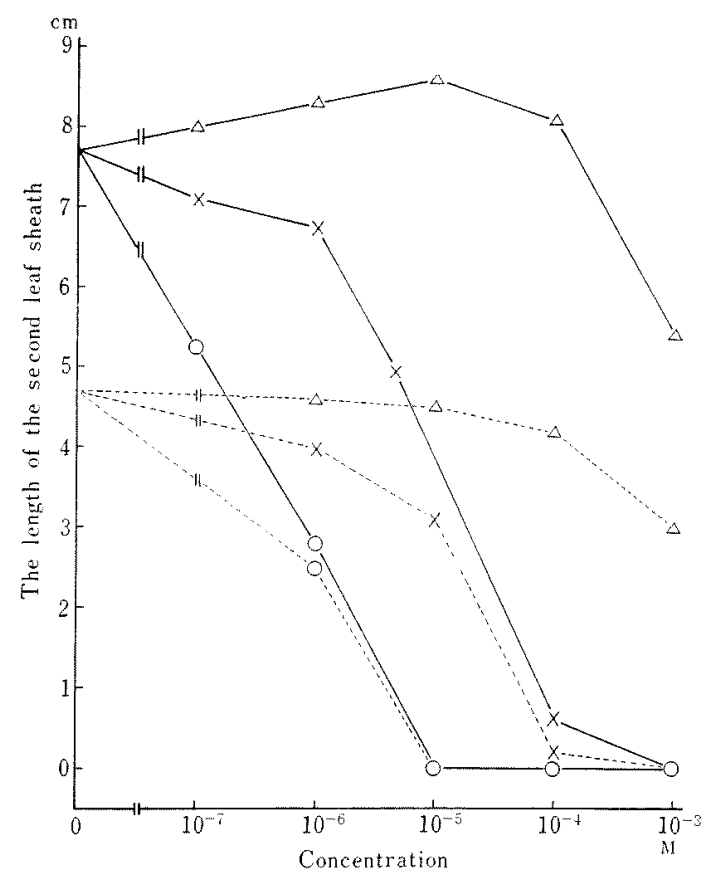

FIG, 2. The Growth of Rice Seedlings (Oryzae sativa L. var. Honen-Wase) in 0.7\% Agar Medium with $\mathrm{GA}_{3}\left(10^{-4} \mathrm{M}\right)$ and Containing Inhibitors.

-, After growth at $28^{\circ} \mathrm{C}(2000 \mathrm{lux})$ for 5 days (-..., without $\mathrm{GA}_{3}$ for 6 days), the length of the second leaf sheath was measured.

0 , abscisic acid (Ia); $\times, 2-c i s-\alpha$-ionylideneacetic acid (IIa); $\triangle, \beta$-cyclocitrylideneacetic acid (XXVIa). 
other lower homologs. However, the growth of both seedlings was strongly inhibited by analogs of ionylideneacetic acids, but scarcely inhibited by some of their lower homologs, as shown in Table III. Two compounds, 2-cis3-methyl-phenylpentadienoic acid (XI) and 1 ' - hydroxy - 4' - keto - $\alpha$-cyclocitrylideneacetic acid (XXII), showed weak growth-promoting action on radish seedlings.

Generally in the above bioassay tests, the methyl or ethyl esters of oxygenated ionylideneacetic acids showed stronger activity than their free acids. However, methyl $\alpha$-ionylideneacetate (IIb), which does not possess an oxygen function except for the carboxylic group, showed weaker activity than its free acid (IIa). Generally ABA showed the strongest activity among analogs of ionylideneacetic acids in the above bioassay tests. This probably means that analogs of ionylideneacetic acids may become effective as a result of enzymatic conversion into ABA in plants, as suggested in another paper. ${ }^{\text {? }}$ The conversion of IXa into ABA in plants has already been

Table I. The Growth-Inhibitory Activity of Compounds Related To ABA ON Phaseolus angularis L. SeEdlings

$\%$ Inhibitory activity $($ control $=0$, Complete inhibition $=100$ )

\begin{tabular}{|c|c|c|c|c|c|c|}
\hline \multirow{2}{*}{$\begin{array}{l}\text { Concn. } \\
\text { Compound No. }\end{array}$} & \multicolumn{2}{|c|}{$10^{-3} \mathrm{M}$} & \multicolumn{2}{|c|}{$10^{-4} \mathrm{M}$} & \multicolumn{2}{|c|}{$10^{-5} \mathrm{M}$} \\
\hline & $F^{b}$ & $S^{b r}$ & $\mathrm{~F}$ & $S$ & $\mathbf{F}$ & $\mathrm{S}$ \\
\hline$I(A B A)$ & $100^{\circ}$ & 100 & 55 & 94 & 35 & 47 \\
\hline IIa & 65 & 99 & 25 & 30 & 2 & 15 \\
\hline $\mathrm{Ilb}$ & 35 & 45 & 0 & 0 & 0 & 0 \\
\hline IIIa & 45 & 60 & 0 & 5 & 0 & 0 \\
\hline IIIb & 90 & 98 & 5 & 85 & 40 & 0 \\
\hline V & 40 & 85 & 0 & 10 & 0 & 0 \\
\hline $\mathrm{IXa}$ & 90 & 100 & 30 & 45 & 0 & 0 \\
\hline $\mathrm{IXb}$ & 20 & 50 & 10 & 30 & 0 & 0 \\
\hline $\mathrm{X}$ & 5 & 65 & 0 & 15 & 0 & 0 \\
\hline XI & 3 & 34 & 0 & 10 & 0 & 0 \\
\hline XII & 15 & 80 & 0 & 0 & 0 & 0 \\
\hline XIII & 45 & 90 & 10 & 0 & 0 & 0 \\
\hline XIV & 0 & 5 & 0 & 0 & 0 & 0 \\
\hline $\mathrm{XV}$ & 0 & 5 & 0 & 0 & 0 & 0 \\
\hline XVI & 0 & 15 & 0 & 0 & 0 & 0 \\
\hline XVII & 10 & 35 & 0 & 7 & 0 & 0 \\
\hline XVIII & 0 & 6 & 0 & 0 & 0 & 0 \\
\hline $\mathrm{XIX}$ & 10 & 10 & 0 & 0 & 0 & 0 \\
\hline $\mathrm{XX}$ & 5 & 20 & 0 & 0 & 0 & 0 \\
\hline $\mathrm{XXI}$ & 10 & 60 & 0 & 30 & 0 & 0 \\
\hline XXII & 10 & 60 & 0 & 10 & 0 & 0 \\
\hline XXIII & 47 & 60 & 0 & 20 & 0 & 0 \\
\hline XXIV & 48 & 70 & 10 & 35 & 0 & 0 \\
\hline $\mathrm{XXV}$ & 6 & 15 & 0 & 0 & 0 & 0 \\
\hline XXVIa & 40 & 90 & 0 & 20 & 0 & 0 \\
\hline XXVIb & 7 & 50 & 0 & 5 & 0 & 0 \\
\hline XXVII & 30 & 80 & 0 & 40 & 0 & 0 \\
\hline XXVIII & 5 & 40 & 0 & 5 & 0 & 0 \\
\hline XXIX & 70 & 90 & 0 & 10 & 0 & 5 \\
\hline $\mathrm{XXX}$ & 15 & 20 & 0 & 0 & 0 & 0 \\
\hline $\mathrm{XXXI}$ & 10 & 30 & 0 & 0 & 0 & 0 \\
\hline
\end{tabular}

a) F: Growth inhibition of the first internode.

b) S: Growth inhibition of the second internode plus the third.

c) After growth at $28^{\circ} \mathrm{C}(2000 \mathrm{lux})$ for 5 days, the effects on epicoty elongation were measured. 
Table II. The Germination-inhibitory Activity of Compounds Related TO ABA ON SOME SPECIES OF SEEDS $\%$ Germination-inhibitory ratio (control $=0$, complete inhibition $=100$ ) at concn. of $10^{-4} \mathrm{M}$.

\begin{tabular}{|c|c|c|c|c|}
\hline \multirow{2}{*}{ Compound No. } & \multirow{2}{*}{ Leaf mustard } & \multirow{2}{*}{ French Marigold } & \multicolumn{2}{|c|}{ Lettuce } \\
\hline & & & light & dark \\
\hline I (ABA) & $90^{a b} \mathrm{gi}^{b_{1}}$ & 100 & 100 & 100 \\
\hline Ila & 75 & 70 & 100 & 95 \\
\hline $\mathrm{IIb}$ & 60 & 35 & 85 & 10 \\
\hline IIIa & 20 & 35 & 85 & 40 \\
\hline IIIb & 100 & 98 & 100 & 80 \\
\hline $\mathrm{V}$ & 0 & 20 & 90 & 40 \\
\hline $\mathrm{IXa}$ & 0 & 25 & 95 & 80 \\
\hline $\mathrm{IXb}$ & $35 \mathrm{gi}$ & $80 \mathrm{gi}$ & 98 & 95 \\
\hline $\mathrm{X}$ & $40 \mathrm{gi}$ & 95 & 90 & 40 \\
\hline XI & 0 & 20 & 20 & 15 \\
\hline XII & $75 \mathrm{gi}$ & 25 & 100 & 25 \\
\hline XIII & 45 & 20 & 75 & 0 \\
\hline XIV & 0 & 30 & 0 & 0 \\
\hline XV & 0 & 0 & 0 & 0 \\
\hline XVI & 0 & 0 & 35 & 0 \\
\hline $\mathrm{XVII}$ & 0 & 5 & 0 & 0 \\
\hline XVIII & 0 & 5 & 5 & 0 \\
\hline XIX & 0 & 10 & 0 & 0 \\
\hline $\mathrm{XX}$ & 5 & 0 & 0 & 0 \\
\hline $\mathrm{XXI}$ & 5 & 0 & 30 & 20 \\
\hline XXII & 0 & 0 & 0 & 10 \\
\hline XXIII & 0 & 0 & 30 & 0 \\
\hline XXIV & 0 & 0 & 0 & 0 \\
\hline $\mathrm{XXV}$ & 0 & 0 & 0 & 0 \\
\hline XXVIa & 0 & $20 \mathrm{gi}$ & 30 & 20 \\
\hline XXVIb & 0 & 0 & 20 & 0 \\
\hline XXVII & 0 & $30 \mathrm{gi}$ & 10 & 0 \\
\hline XXVIII & 0 & 0 & 0 & 0 \\
\hline XXIX & 0 & $20 \mathrm{gi}$ & 20 & 10 \\
\hline $\mathrm{XXX}$ & 0 & 5 & 0 & 0 \\
\hline $\mathrm{XXXI}$ & 0 & 0 & 50 & 0 \\
\hline
\end{tabular}

b) After germination at $28^{\circ} \mathrm{C}$ (2000 lux) for 2 (leaf mustard), 3 (French Marigold), 5 (lettuce in light) and 3 days (lettuce in the dark), \% germination-inhibitory ratios were measured.

b) gi: strong growth inhibition of seedlings.

demonstrated by Milborrow et al. ${ }^{s}$ and this is considered to support the above view. Probably the low activity of methyl 3'-hydroxy$\beta$-ionylideneacetate (V) indicates difficulty in converting it into ABA in plants.

\section{EXPERIMENTAL}

Syntheses of test compounds

1) Selenium dioxide oxidation of methyl 2-cis-aionylideneacetate $(\mathrm{IIb})$. To a stirred solution of $\mathrm{IIb}$ $(1.2 \mathrm{~g})$ in $250 \mathrm{ml}$ of $95 \%$ ethanol was added dropwise an etratolic $\mathrm{SeO}_{2}$ solution (prepared from $1.0 \mathrm{~g}$ of $\mathrm{SeO}_{2}$ and $150 \mathrm{ml}$ of ethanol) at room temperature for $1 \mathrm{hr}$ and the mixture was further stirred for 6 days at room temperature. After evaporation of the ethanol the residual oil was chromatographed on silica-gel. Elution with benzene gave $120 \mathrm{mg}$ of crude $\mathrm{IIb}$. Further elution with benzene-ethyl acetate (4:1) gave $195 \mathrm{mg}$ of methyl 2-cis-1'-hydroxy-a-ionylideneacetate (IIIb) as the first fraction ( $R f: 0.85$ on silica-gel TLC Merck $H$, developing with benzene-ethyl acetate (4:1)), a mixture of methyl 2-cis-4'-hydroxy-a-ionylideneacetate (IV) and methyl 2 -cis- and trans $-3^{\prime}$-hydroxy- $\beta$ ionylideneacetates as the second fraction $(300 \mathrm{mg})$ and 
Table III. The Germination and Growth-inhibitory Activities of Compounds Related to ABA on SeEds of Radish and OAT

$\%$ Inhibitory ratio (control $=0$, complete inhibition $=100$ ) at concn. of $10^{-4} \mathrm{M}$

\begin{tabular}{|c|c|c|c|c|}
\hline \multirow{2}{*}{ Compound No. } & \multicolumn{2}{|c|}{ Radish } & \multicolumn{2}{|c|}{ Oat } \\
\hline & Germ $^{a}$ & Growth $^{b}$ & Germ & Growth \\
\hline $\mathrm{I}(\mathrm{ABA})$ & $50^{c}$ & 100 & 60 & 100 \\
\hline IIa & 25 & 60 & 0 & 89 \\
\hline IIb & 15 & 40 & 0 & 75 \\
\hline IIIa & 0 & 30 & 0 & 25 \\
\hline IIIb & 70 & 100 & 0 & 0 \\
\hline V & 10 & 60 & 20 & 8 \\
\hline IXa & 20 & 40 & 10 & 98 \\
\hline $\mathrm{IXb}$ & 30 & 60 & 10 & 100 \\
\hline $\mathrm{X}$ & 10 & 60 & 10 & 98 \\
\hline $\mathrm{XI}$ & 0 & $\mathrm{p}^{d t}$ & 0 & 18 \\
\hline XII & 10 & 70 & 0 & 90 \\
\hline XIII & 0 & 35 & 0 & 35 \\
\hline XIV & 0 & 0 & 0 & 0 \\
\hline$X V$ & 0 & 0 & 0 & 0 \\
\hline XVI & 0 & 0 & 0 & 0 \\
\hline XVII & 0 & 0 & 0 & 0 \\
\hline XVIII & 5 & 0 & 0 & 5 \\
\hline XIX & 10 & 25 & 0 & 10 \\
\hline$x x$ & 0 & 0 & 0 & 0 \\
\hline XXI & 0 & 0 & 10 & 20 \\
\hline XXII & 0 & $\mathrm{p}$ & 0 & 0 \\
\hline XXIII & 0 & 0 & 0 & 0 \\
\hline XXIV & 0 & 0 & 0 & 10 \\
\hline XXV & 0 & 0 & 0 & 0 \\
\hline XXVIa & 0 & 0 & 10 & 0 \\
\hline XXVIb & 5 & 0 & 15 & 0 \\
\hline XXVII & 0 & 0 & 0 & 20 \\
\hline XXVIII & 0 & 0 & 0 & 0 \\
\hline XXIX & 0 & 0 & 0 & 0 \\
\hline $\mathrm{XXX}$ & 0 & 0 & 0 & 0 \\
\hline XXXI & 0 & 0 & 0 & 0 \\
\hline
\end{tabular}

a) Germ: The germination-inhibitory ratio.

b) Growth: The growth-inhibitory ratio of germinated seedlings.

c) After germination and growth at $28^{\circ} \mathrm{C}$ (2000 lux) for 3 (radish) and 5 days (oat), \% inhibitory ratios were measured.

d) p: Growth-promoting action on germinated seedlings.

$360 \mathrm{mg}$ of methyl 2 -cis-3'-hydroxy- $\beta$-ionylideneacetate (V). Preparative silica-gel TLC $\left(\right.$ Merck $\left.\mathrm{PF}_{254}\right)$ of the second fraction (100 $\mathrm{mg}$ ) afforded $11.5 \mathrm{mg}$ of IV and then a mixture of methyl 2-cis and trans-3'-hydroxy- $\beta$ ionylideneacetates (about $1: 2$ ). $R f$ values on TLC as described above: 0.62 for IV, 0.36 for $V, 0.43$ for the 2-trans form of V. Similar oxidation of IIb $(1.2 \mathrm{~g})$ with $\mathrm{SeO}_{2}(800 \mathrm{mg})$ in ethanol under reflux for $16 \mathrm{hr}$ gave $350 \mathrm{mg}$ of IIb, $465 \mathrm{mg}$ of the monohydroxy-esters and $130 \mathrm{mg}$ of the dihydroxy-esters, which were separated by silica-gel column chromatography, developing with benzene-ethyl acetate $(4: 1 \sim 1: 1)$. The latter fraction contained three components on TLC as described above ( $R f: 0.13,0.19$ and 0.28 ) and was oxidized with active $\mathrm{MnO}_{2}(7.0 \mathrm{~g})$ in $20 \mathrm{ml}$ of $\mathrm{CHCl}_{3}$ for 2 days to give $25 \mathrm{mg}$ of methyl abscisate (Ib), which was separated by silica-gel column chromatography and identified with an authentic sample. IIIb, NMR $\left(\mathrm{CCl}_{4}\right) \delta: 0.88(s, 3 \mathrm{H}), 0.98(s, 3 \mathrm{H}), 1.61(s, 3 \mathrm{H}), 2.00$ $(s, 3 \mathrm{H}), 3.63(s, 3 \mathrm{H}), 5.45(1 \mathrm{H}), 5.55(s, 1 \mathrm{H}), 6.05(d, 1 \mathrm{H}$, $J=15 \mathrm{~Hz}), 7.50(d, 1 \mathrm{H}, J=15 \mathrm{~Hz})$ IV, NMR $\left(\mathrm{CCl}_{4}\right) \delta$ : $0.90(s, 3 \mathrm{H}), 1.0(s, 3 \mathrm{H}), 1.65(s, 3 \mathrm{H}), 2.00(s, 3 \mathrm{H})$, 
$3.65(s, 3 \mathrm{H}), 6.00(d, 1 \mathrm{H}, J=15 \mathrm{~Hz}), 7.68(d, 1 \mathrm{H}, J=$ $15 \mathrm{~Hz}), 5.53(2 \mathrm{H}) . \quad$ IR $\nu_{\mathrm{max}}^{\mathrm{film}} \mathrm{cm}^{-1}: 3520,1720,1630$, $1600,1380,1230,1160,1045,920$. UV $\lambda_{\max }^{\mathrm{EtoH}} \mathrm{nm}: 276.5$. $\mathrm{V}, \operatorname{NMR}\left(\mathrm{CCl}_{4}\right) \delta: 1.05(s, 3 \mathrm{H}), 1.08(s, 3 \mathrm{H}), 1.82(s, 3 \mathrm{H})$, $2.05(s, 3 \mathrm{H}), 3.60(s, 3 \mathrm{H}), 3.82(1 \mathrm{H}), 5.55(s, 1 \mathrm{H}), 6.42$ $(d, 1 \mathrm{H}, J=16.5 \mathrm{~Hz}), 7.58(d, 1 \mathrm{H}, J=16.5 \mathrm{~Hz})$.

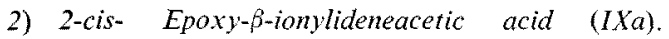
Methyl 2-trans- $\beta$-ionylideneacetate (VII), prepared from $\beta$-ionone $(\mathrm{XX})$, was epoxidized with perbenzoic acid in chloroform and then hydrolyzed with aqueous potassium hydroxide to give 2-trans-epoxy- $\beta$-ionylideneacetic acid (VIII), mp $105 \sim 107^{\circ} \mathrm{C}$. Irradiation of VIII (1.0 g) in $25 \mathrm{ml}$ of ethyl acetate with an ultra violet ray lamp $(100 \mathrm{~W})$ for $2 \mathrm{hr}$ gave a mixture of the 2-cis and trans acids (1:1). Recrystallization of the mixture from acetonitrile afforded 2 -cis-epoxy- $\beta$-ionylideneacetic acid (IXa), mp $146 \sim 147^{\circ} \mathrm{C}$. Similar irradiation of ethyl 2-trans-epoxy- $\beta$-ionylideneacetate, followed by silica-gel column chromatography, afforded ethyl 2-cis-epoxy$\beta$-ionylideneacetate (IXb) as an oil. NMR $\left(\mathrm{CCl}_{4}\right) \dot{0}$ : $0.92(s, 3 \mathrm{H}), 1.08(s, 3 \mathrm{H}), 1.13(s, 3 \mathrm{H}), 1.25(t, 3 \mathrm{H})$, $1.97(s, 3 \mathrm{H}), 4.02(q, 2 \mathrm{H}), 5.47(s, 1 \mathrm{H}), 6.00(1 \mathrm{H}, d$, $J=15 \mathrm{~Hz}), 7.35(d, 1 \mathrm{H}, J=15 \mathrm{~Hz})$.

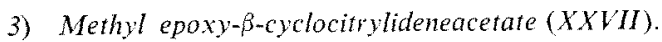
Epoxidation of methyl $\beta$-cyclocitrylideneacetate (XXVIb), which was obtained by methylation of $\beta$ cyclocitrylideneacetic acid (XXVIa), mp $102 \sim 103^{\circ} \mathrm{C}$ (from $n$-hexane) with diazomethane, in chloroform at $5^{\circ} \mathrm{C}$ gave XXVII as an oil, which was purified by silicagel column chromatography. NMR $\left(\mathrm{CCl}_{4}\right) \hat{\delta}: 0.92(s$, $3 \mathrm{H}), 1.13(s, 3 \mathrm{H}) 1.15(s, 3 \mathrm{H}), 3.68(s, 3 \mathrm{H}), 5.90(d, 1 \mathrm{H}$, $J=16 \mathrm{~Hz}), 7.05(d, 1 \mathrm{H}, J=16 \mathrm{~Hz})$. UV $\lambda_{\mathrm{max}}^{\mathrm{EtOH}} \mathrm{nm}: 222$ $\left(E_{1 \mathrm{C}}^{1 \%}=5250\right)$.

4) Ethyl2-cis and trans-farnesoates ( $X V$ and $X V I)^{9 !}$ Wittig reaction of trans-geranylacetone with carbethoxymethylenetriphenylphosphorane at $170 \sim 180^{\circ} \mathrm{C}$ for $2 \mathrm{hr}$ afforded ethyl 2-cis and trans farnesoates (about 1:1 mixture), which were chromatographed on silicagel. Elution with benzene gave ethyl 2-trans farnesoate (XVI) as an oil, followed by ethyl 2-cis farnesoate (XV) as an oil. Gas chromatographic analysis with $30 \%$ SE-30 on celite $545(1.5 \mathrm{~m} \times 3 \mathrm{~mm})$, column temp. $214^{\circ} \mathrm{C}$, He flow rate: $15 \mathrm{cc} / \mathrm{min}\left(1.6 \mathrm{~kg} / \mathrm{cm}^{2}\right)$, retention time: $8.2 \mathrm{~min}$ for $\mathrm{XV}$ and $7.2 \mathrm{~min}$ for $\mathrm{XVI}$. XV, NMR $\left(\mathrm{CCl}_{4}\right) \delta: 1.25(t, 3 \mathrm{H}), 1.56(s, 3 \mathrm{H}), 1.85(s, 3 \mathrm{H})$, $1.95(s, 3 \mathrm{H}), 4.05(q, 2 \mathrm{H}), 5.00(2 \mathrm{H}), 5.55(s, 1 \mathrm{H})$. $\operatorname{IR} \nu_{\max }^{\mathrm{film}} \mathrm{cm}^{-1}: 1725,1644,1375,1220,1145$. XVI, $\operatorname{NMR}\left(\mathrm{CCl}_{4}\right) \delta$ : $1.25(t, 3 \mathrm{H}), 1.56(s, 3 \mathrm{H}), 1.65(s, 3 \mathrm{H})$, $1.95(s, 3 \mathrm{H}), 2.10(s, 3 \mathrm{H}), 4.05(q, 2 \mathrm{H}), 5.00(2 \mathrm{H}), 5.55$ $(s, 1 \mathrm{H}) . \quad$ IR $\nu_{\max }^{\text {film }} \mathrm{cm}^{-1}: 1725,1642,1355,1220,1155$.

5) Other test compounds. ( \pm -Abscisic acid (Ia), and racemic analogs of IIa, XIX, XXIV and XXX were used for growth assay. ( \pm )-Ethyl 4'-keto- $\alpha$-ionylidene- acetate $(\mathrm{X})$ a stereoisomeric mixture of 2-cis and trans forms ( $1: 1)$ was prepared by tert-butyl chronate oxidation of ethyl 2-cis and trans- $\alpha$-ionylideneacetates $(4: 6$ mixture) and purified by preparative silica-gel TLC (Merck $\mathrm{PF}_{254}$ ) for growth assay. Farnesol (XVI) was purchased from Firmanich Co. Ltd.

\section{Bioassay procedure}

Azuki bean seedling growth. Azuki bean seedlings were grown in sunny fields under natural conditions (mainly from May 1 to June 25, 1973, average temperature: $15 \sim 20^{\circ} \mathrm{C}$ ) before the following test. In winter, Azuki bean seedlings were grown from seeds in moist Vermiculite at $25^{\circ} \mathrm{C}$ (2000 lux). Better results were obtained using the former seedlings than the latter. Azuki bean seeds (Phaseolus angularis. var. Dainagon) were sown in moist soil and grown for about two weeks and uniform seedlings were selected for the tests. Average length of seedlings before the test: Epicotyl $5.5 \sim 6.0 \mathrm{~cm}$. Two barerooted seedlings were grown per $200 \mathrm{ml}$ beaker, which contained $20 \mathrm{ml}$ of a $10^{-1} \mathrm{M}$ acetone solution, prepared from $0.1 \%$ Hyponex nutrient solution and test compounds $\left(10^{-3} \sim 10^{-4} \mathrm{M}\right)$, at $27 \sim$ $28^{\circ} \mathrm{C}$ under continuous illumination (2000 lux) for 5 days. The effect on stem elongation between the cotyledonary node and terminal meristem (the length of the epicotyl) was measured on $2 \sim 3$ replicas for each compound. Length of the control test: Length of the first internode; $14.0 \sim 15.0 \mathrm{~cm}$, length of the second internode plus the third internode; $6.0 \sim 6.5 \mathrm{~cm}$. The average inhibitory activity found is shown in Table $\mathrm{I}$ in terms of percent growth inhibition (control= $0 \%$, complete inhibition $=100 \%$ ).

Rice seedling test. Rice seedlings (Honen-Wase, an ordinary variety of Oryzae sativa L.), which were sterilized with $0.1 \% \mathrm{HgCl}_{2}$ solution and germinated in water for 3 days at $27 \mathrm{C}$, were grown on $40 \mathrm{ml}$ of $0.7 \%$ agar medium in $7.0 \mathrm{~cm}$ Petri plates (10 seedlings per dish). After growing at $27 \sim 28^{\circ} \mathrm{C}$ for $5 \sim 6$ days, the length of the second leaf sheath (distance from the coleoptile joint to the second leaf joint, in the previous report ${ }^{1 /}$ the distance from the first leaf tip to the second leaf joint) was measured, as shown in Fig. 2.

Seed germination test. Seeds: Radish (Nerima, an ordinary variety of Raphanus sativus L.), French Marigold (Tagetes patula L.) and leaf mustard (Brassica juncea Coss) were germinated in $7.0 \mathrm{~cm}$ Petri plates lined with three disks of filter paper soaked in $10 \mathrm{ml}$ of test solution $\left(10^{-4} \mathrm{M}\right)$. Each experiment was carried out with $2 \sim 3$ replicates of fifty seeds for lettuce and leaf mustard, and twenty seeds for radish or French Marigold. Emergence of the radicle from the seed coat was taken as the criterion of seed germination. Germination was carried out in a humid box at $27 \sim$ $28^{\circ} \mathrm{C}$ in the light (2000 lux) and the number of seeds 
which germinated was counted. The activities were expressed as a percentage compared to the control (Table II). Also, the growth-inhibitory activity of hypocotyls for germinated radish seeds was measured as shown in Table III.

Growth-inhibitory activity and seed germination test of oat. Seeds (Zenshin, an ordinary variety of Avena sativa L.) were germinated and grown in $7.0 \mathrm{~cm}$ Petri plates lined with two disks of filter paper soaked in $10 \mathrm{ml}$ of test sample solution $\left(10^{-4} \mathrm{M}\right)$ at $27^{\circ} \mathrm{C}$ (2000 lux) for 5 days. The number of germinated seeds was counted and the length of the leaf sheath was measured, as shown in Table III.

\section{REFERENCES}

1) T. Oritani and K. Yamashita, Agr. Biol. Chem.,
34, 108 (1970).

2) T. Oritani and K. Yamashita, ibid., 34, 830 (1970); 36, 362 (1972).

3) T. Oritani and K. Yamashita, ibid., 34, 198 (1970).

4) T. Oritani and K. Yamashita, ibid., 34, 1821 (1970).

5) I. C. Popoff, R. M. Sachs and J. B. Gibbs, J. Agr. Food Chem., 20, 665 (1972).

6) S. Tamura and M. Nagao, Agr. Biol. Chem., 34, 1393 (1970).

7) T. Oritani and K. Yamashita, Collected Abstracts of the 8th International Conference on Plant Growth Substance, 1973, p. 116; Proceedings "Plant Growth Substances 1973" in press.

8) B. V. Milborrow and M. Carmston, Phytochemistry, 12, 1597 (1973).

9) L. A. Yanovskaya and V. F. Kucherov, Izu. Akad. Nauk SSSR, Ser. Khim., 1964, 1341 [C.A., 61, 11887 (1964)]. 